\title{
D. GEORGE SHERMAN
}

$$
\text { (1947-1992) }
$$

D. George Sherman died in a car accident on November 16, 1992. Dr. Sherman received his Ph.D. in anthropology from Cornell University in 1981, based on two and a half years of research (1975-78) among the Samosir Batak, in North Sumatra, Indonesia. Publications based on this research include a pioneering article in the journal Indonesia (1980), "What 'Green Desert'? The Ecology of Batak Grassland Farming." He also is the author of "Men who are called 'women' in Toba-Batak marriage" in the American Antbropologist (1990), and a major 1990 publication by Stanford University Press, Rice, Rupees, and Ritual: Economy and Society among the Samosir Batak. In-progress works include an edited collection of essays on grassland ecology and a monograph on the anthropology of Nazi ideology. Dr. Sherman had taught at the University of Illinois, the University of California at Irvine, and Dartmouth College and, at the time of his death, was teaching at Keene State College in New Hampshire while residing with his daughter, Ruth, in Wendell, Massachusetts. Here he had co-founded a communal farm in the 1960s and had continued to be active in local environmental and civic affairs. Dr. Sherman will be remembered and missed by all who knew him for his meticulous scholarship, his unflagging moral commitment, and his generous and open heart.

Michael R. Dove

East-West Center 